\title{
THE FELON'S RESPONSIBILITY FOR THE LETHAL ACTS OF OTHERS
}

\section{Norval Morris $†$}

Far from shrinking under protracted criticism, the felony-murder rule has recently demonstrated a tendency to expand. In particular, courts in Pennsylvania and California have greatly extended the scope of this doctrine. Though their purpose of deterring the commission of certain felonies is commendable, the means selected appears to be socially unwise and is based on reasoning not free from substantial analytic and historical errors.

Throughout the Anglo-American system of criminal justice, those who engage in certain felonies and kill the subject of their felonious designs, or those who kill while forcibly resisting lawful arrest, may be convicted of murder. Where, however, death is caused by the retaliatory or defensive action of a victim of an intended felony, or by a police officer or other person assisting him, the criminal responsibility of the felon for that death is less clear. In such circumstances an innocent bystander, a policeman or one of the felons may be killed by an act of justified resistance to the felony or by an act intended to prevent the criminal's escape. Are the felons, by virtue of their felony, murderers?

Likewise, if during the course of a felony one of the felons from extraneous motives kills one of his fellow conspirators, the criminal liability of the surviving conspirators, other than the actual killer, is uncertain.

Decisions in Pennsylvania and California have held the surviving felons guilty of murder in the first degree in all the above situations. It is proposed to review these cases, to search out the suggested basis of liability, and to urge the repudiation of this extension of the felonymurder rule. Finally, two kindred topics involving the limits of a felon's liability for the lethal acts of his co-felon will be considered. ${ }^{1}$

$\dagger$ Associate Professor of Criminology and Senior Lecturer in Law, University of Melbourne.

1. The leading commentary on these and kindred problems is Wechsler \& Michael, $A$ Rationale of the Law of Homicide, 37 CoLUM. L. REv. 701, 1261 (1937). See also Crum, Causal Relations and the Felony-Murder Rule, 1952 WASH. U.L.Q. 191; Hitchler, The Killer and His Victim in Felony-Murder Cases, 53 DICK. L. REv. 3 (1948); Moesel, A Survey of Felony Murder, 28 TEMP. L.Q. 453 (1955) ; Perkins, The Law of Homicide, 36 J. CRIM. L., C. \& P.S. 391 (1946); Perkins, A Re-Examiration of Malice Aforethought, 43 YALE L.J. 537 (1934). 


\section{Retaliatory Lethal Force}

In Commonzealth $v$. Almeida ${ }^{2}$ the accused and two confederates committed an armed robbery. In attempting to escape, one or more of the felons fired several shots at policemen, who returned the fire. One policeman was shot and killed. The Pennsylvania Supreme Court held that Almeida could be convicted of murder in the first degree even if the lethal shot came from a policeman's gun. In Commonwealth $v$. Wilson, Judge Curtis Bok, following Almeida, told the jury that if they found that Wilson and his confederate were engaged upon a robbery when they were interrupted by the police, and if, in the ensuing chase, a policeman accidentally or intentionally shot Wilson's confederate, they should convict Wilson of murder in the first degree. Finally, in Commonwealth v. Thomas, ${ }^{4}$ the Pennsylvania Supreme Court, on facts agreed upon demurrer, held that Thomas could be convicted of murder in the first degree of his co-felon, Jackson, if Jackson met his death from a bullet fired by the shopkeeper whom they had robbed.

In all these cases, the relevant statute provided merely that: "All murder . . . which shall be committed in the perpetration of . .. robbery . . . shall be deemed murder in the first dergee." 5 In Pennsylvania, as in most jurisdictions, the term "murder" is not statutorily defined and it is to the common law that one must look for its definition. ${ }^{6}$

Almeida was considered on the assumption of fact that officer Ingling, endeavoring to effect the arrest of the accused, an armed robber resisting arrest, was accidentally shot by another policeman. ${ }^{7}$ The court held this to be murder on the following reasoning: the decision in the prior Pennsylvania case of Commonwealth v. Moyer, ${ }^{8}$ which the trial judge followed in the instant case, was based on the principle that "he whose felonious act is the proximate cause of another's

2. $362 \mathrm{~Pa} .596,68$ A.2d 595 (1949), cert. denied, 339 U.S. 924 (1950).

3. Philadelphia County C.P. No. 6, Feb. Sess. 1953. Transcript of his charge to the jury kindly supplied by Judge Curtis Bok.

4. $382 \mathrm{~Pa} .639,117$ A.2d 204 (1955).

5. Pa. Stat. Ans. tit. 18, §4701 (1945).

6. In all states other than Florida, Louisiana, Minnesota, Mississippi, New York, Oklahoma, South Dakota, Washington and Wisconsin the common-law definition of murder serves as an integral part of the statute law of the state on homicide. These nine states, however, have developed statutory definitions of murder which do not rely directly on the common law: Fra. Srat. \$ 782.04 (1941) ; LA. REv. STAT. \$ 14:30 (1950); Minn. Stat. Ann. \$619.07 (1947); Miss. Cone AnN. §2215 (1944); N.Y. PEN. LaW \$1044; Okra. Stat. ANn. tit. 21, \$701 (1937); S.D. Code \$ 13.2007 (1939) ; Wash. Rev. Code $\$ 9.48 .040$ (1951); Wisc. Stat. $\$ \$ 940.01-.03$ (1955). See also Perkins, The Law of Homicide, 36 J. Crim. L., C. \& P.S. 391 (1946).

7. $362 \mathrm{~Pa}$. at $599,68 \mathrm{~A} .2 \mathrm{~d}$ at 597.

8. 357 Pa. 181, 53 A.2d 736 (1947). 
death is criminally responsible for that death and must answer to society for it exactly as he who is negligently the proximate cause of another's death is civilly responsible for that death and must answer in damages for it." $\theta$ The court went on, quite inaccurately, to state that commentators are agreed that "the rules of proximate cause are the same in crime as in tort," 10 and that "courts in the United States, England and Canada have applied the foregoing principles of "proximate cause' in murder cases, as the cases now to be cited and reviewed in this opinion demonstrate." 11

Except for the dissenting view in the case of The King $v$. Hodgson, ${ }^{12}$ all of the cases relied on by the majority in Almeida fall within three categories which, it will later be submitted, ${ }^{13}$ are readily distinguishable from the problem posed in Almeida. The court, however, advanced all these cases together as supporting the proposition that "a knave who feloniously and maliciously starts a "chain reaction' of acts dangerous to human life must be held responsible for the natural fatal results of such acts," ${ }^{14}$ and that this responsibility is by statute responsibility for murder in the first degree.

The majority in Almeida distinguished the decisions or dicta in four apparently contradictory cases, ${ }^{15}$ refused to follow one clearly opposing case," and affirmed that "no decision of this court . . . has ever ruled contrary to what we are ruling on this question." 17

Only two other links in the court's chain of reasoning in Almeida need to be noted. Cases and authorities were advanced to show that,

9. $362 \mathrm{~Pa}$. at $603,68 \mathrm{~A} .2 \mathrm{~d}$ at 599 .

10. Id. at 605,68 A.2d at 600 . Commentators would appear to be in considerable conflict on this issue. To name only two leading writers, Green, Are There Dependable Rules of Causation?, 77 U. PA. L. REv. 601 (1929) and Sayre, Criminal Responsibility for the Acts of Another, 43 HARV. L. REv. 689 (1930) are in disagreement with the court's view. The court's citation of textual authority on this question is most misleading. A statement from WHARTON, HOMICIDE 30 (3d ed. 1907) is quoted as supporting the court's decision. $362 \mathrm{~Pa}$. at $604,68 \mathrm{~A} .2 \mathrm{~d}$ at 600 . A reading of the full text of Wharton on the page quoted reveals that his opinion has not been accurately presented. Likewise, a quotation from GreEN, Ratronale of Proximate CAUSE 13233 (1927) is offered, $362 \mathrm{~Pa}$, at $606,68 \mathrm{~A} .2 \mathrm{~d}$ at 600 , which gives a misleading impression, particularly in the light of Professor Green's later writings, e.g., Green, supra.

11. $362 \mathrm{~Pa}$. at $606,68 \mathrm{~A} .2 \mathrm{~d}$ at $600-01$.

12. 1 Leach 7, 168 Eng. Rep. 105 (1730).

13. See pp. $62-69$ infra.

14. $362 \mathrm{~Pa}$. at 634,68 A.2d at 614.

15. Butler v. People, 125 Ill. 641, 18 N.E. 338 (1888) ; People v. Udwin, 254 N.Y. 255, 172 N.E. 489 (1930) ; Commonwealth v. Thompson, 321 Pa. 327, 184 Atl. 97 (1936) ; Commonwealth v.'Mellor, 294 Pa. 339, 144 At1. 534 (1928).

16. Commonwealth v. Campbell, 89 Mass. (7 Allen) 541 (1863).

17. 362 Pa. at 626,68 A.2d at 610. People v. Garippo, 292 I11. 293, 127 N.E. 75 (1920) was also discussed. This is an unhelpful decision because of the lack of clarity on the facts at issue. Garippo and three others had conspired to commit robbery. One of their number was killed. There was no evidence establishing how he was killed nor indeed that the killing was in any way connected with the felony. 
adopting Professor Beale's view, "all liability is based on proximate cause," and that "the same principles determine criminal responsibility as determine civil liability." 19 It is very doubtful whether this proposition is correct, ${ }^{20}$ but such differences as there may be between the theory of causation in criminal and in civil law are not essential to the problems we are considering, and for the purpose of the present discussion the equation between the two can be accepted.

Finally, the majority roundly affirmed that:

"There can be no doubt about the justice of holding that felon guilty of murder in the first degree who engages in a robbery or burglary and thereby inevitably calls into account defensive forces against him, the activity of which forces result in the death of a human being. Neither can there be any doubt about the general utility of a ruling which holds . . . Almeida guilty of murder of Officer Ingling, even if it had been established that the bullet which killed the officer was fired by one of the police officers." 21

When sincere opinions are in conflict, as they were in this case, the paths of "justice" and "general utility" are rarely as obvious as the majority suppose; heated rhetoric is more frequently the product of emotional reaction than of a careful balancing of the alternatives.

In dissent, Justice Jones stated that "on proof of no more than the perpetration of a felony and an incidental killing, liability for

18. Beale, Recovery for Consequences of an Act, 9 HARV. L. REv. 80, 84 (1895).

19. This line of argument was stated in more immediate terms by the court as follows: "If Mrs. Ingling should bring an action in tort against Almeida and his confederates for causing the death of her husband there is no doubt of her ability to recover a judgment against them .... [W] [Wy should not Almeida be held criminally, as well as civilly, responsible for officer Ingling's death?" $362 \mathrm{~Pa}$. at $630,68 \mathrm{~A} .2 \mathrm{~d}$ at 612. Posing the problem in this way overlooks the very real differences in purpose between the law of torts and the criminal law. The similarity or even identity of rules of remoteness, or proximate cause, between these two areas of the law does not at all preclude Almeida from being civilly liable in some jurisdictions to Mrs. Ingling for the death of her husband and at the same time not responsible as a murderer in the first degree for his death. It presupposes, further, that there is no doubt of the category of crime for which he may be responsible.

20. See, e.g., Sayre, supra note 10 , at 689 , in which several compelling distinctions are drawn between the rules of causation in tort and in crime, particularly where one person is to be held responsible for another's act. To like effect, "The objectives of tort and criminal law are so divergent, however, that . . . precedents cannot be used interchangeably without confusion in both fields of law, with consequent illogical and undesirable results." Note, 96 U. PA. L. REv. 278, 280 (1947). The issue of the identity of the rules of causation in tort and in crime is complicated by the vagueness and unreliability of those rules themselves in both branches of the law. "The phraseology of causation, has never afforded a glimmer of light on any problem a court has had to decide, nor does it provide the slightest articulation for any judgments courts have passed. It has served but one useful function, and that has been to give the judges a dependable way out of difficult situations when they have made up their minds, but either do not know how, or else do not take the time, to articulate their conclusions on a rational basis." Green, supra note 10 , at 626 . See also, HALL, PrincIPLES of Criminat Law 258-59 (1947); Hart \& Honoré, "Causation in the Law," 72 L.Q. REV. 58 (1956).

21. 362 Pa. at 629,68 A.2d at 611 . 
murder can be visited upon the participating felons only where the causation of the homicide is direct, i.e. where one of the felons or one acting in furtherance of the felonious design inflicted the wound." 22 He relied upon the cases which the majority sought to distinguish or refused to follow, ${ }^{23}$ and reconciled the so-called "shield" cases ${ }^{24}$ with his limitation of the felon's liability under the felony-murder rules to directly lethal acts by the felon, arguing that in those cases "the causation requirement for liability is met by instructions to the jury to determine whether the offenders placed their victim in mortal jeopardy for their felonious purpose, e.g. to absorb antagonistic fire or to dissuade antagonists from firing." ${ }^{25}$ If so, it follows that placing the victim in this situation is itself a directly lethal act. ${ }^{26}$

Justice Jones further contended that the question of causation, being a question of fact, should have been left to the jury and should not have been assumed by the trial judge in directing the jury that all they needed to determine to convict Almeida of murder in the first degree was that he was engaged in robbery at the time of the killing. ${ }^{27}$

Further discussion of the Almeida decision may be deferred until the problem posed by it and the two later Pennsylvania cases emerges more clearly. In Commonzvealth $v$. Wilson, the defendant was charged with murder in the first degree, the prosecution's view of the facts being that he and his co-felon, Cave, robbed one Wright; were then

22. Id. at 640,68 A.2d at 617 .

23. See cases cited in notes 15 and 16 supra.

24. I.e., where an innocent bystander, being used as a shield, is killed by a shot directed at the felons. See Wilson v. State, 188 Ark. 846, 68 S.W.2d 100 (1934); Taylor v. State, 63 S.W. 330 (Tex. Crim. App. 1901); Keaton v. State, 41 Tex. Crim. 621, 57 S.W. 1125 (1900); Taylor v. State, 41 Tex. Crim. 564, 55 S.W. 961 (1900).

25. $362 \mathrm{~Pa}$. at $640,68 \mathrm{~A} .2 \mathrm{~d}$ at 617 .

26. A reading of the "shield" cases leads to the view that the majority's refusal to regard them as basing the felon's liability on the compulsion he exercised on the victim in forcing him to act as a shield is inaccurate, that this is in fact the rationale of these decisions, and that they are not based merely on the fact that the killing was a reasonably foreseeable consequence of the original felony.

27. In this dissent Justice Jones allowed room for a possible conviction of murder despite his original proposition requiring for this purpose that the felon's act be the direct cause of death, by stating that "the jury should have been instructed that in order to find the defendant guilty of murder . . they would . . . have to find that the fatal shot was fired by one of the felons, or, if not fired by one of them, that the conduct of the defendant and his accomplice set in motion a chain of events among whose reasonably foreseeable consequences was a killing such as actually occurred." Id. at 643,68 A.2d at 618 . He thus left open the possibility of the jury convicting Almeida of murder in the first degree under the felony-murder rule even on the hypothesis that another police officer shot Officer Ingling. In so holding, Justice Jones considerably weakened the force and cogency of his dissent, making it turn too largely on allocation of the functions between judge and jury, whereas the whole issue is more fundamental than this. In the later case of Thomas he again dissented but wisely withdrew from this limitation on the force of his dissent in Almeida, and cleaved to his essential proposition that the felony-murder rule only applies (stubject to the gloss of the "shield" cases) to a lethal act, intentional or not, by a felon or his co-felon. 
chased in opposite directions by Officers Strange and Ratowski; and that Officer Strange ultimately shot Cave to prevent him from escaping. Wilson denied that he was party to any robbery. Judge Curtis Bok directed the jury to convict Wilson of the murder of Cave if they believed beyond reasonable doubt that he hảd engaged with Cave in a robbery-"If it happens during a robbery, it is murder in the first degree, and you therefore determine basically if a robbery was being committed, because if you decide it was, that carries you the whole distance. If you say yes, a robbery was being committed and Wilson was taking part in it, then the rest follows and he is guilty of murder in the first degree under the law." ${ }^{28}$ Wilson was acquitted. ${ }^{29}$

In Commonwealth $v$. Thomas, the defendant's demurrer to the commonwealth's evidence, based on the assumption of the following facts, was sustained by the trial court as insufficient to support a conviction of murder in the first degree. ${ }^{30}$ Thomas and Jackson held up the grocery store of Cecchini. Jackson covered Cecchini with a revolver while Thomas removed money from the till. Thomas and Jackson ran from the store in opposite directions. Cecchini secured his own pistol and chased Jackson; there was an exchange of shots in which Cecchini killed Jackson. On appeal the Supreme Court of Pennsylvania, by a majority of four to three, reversed and ordered a new trial, thus holding that if upon trial a jury believed the stated facts beyond reasonable doubt, they should convict Thomas of murder in the first degree.

Justice Arnold delivered the judgment of the court. He relied for authority on the Almeida decision and the cases cited therein, and advanced a view of the felony-murder rule as establishing liability for all foreseeable consequences of the felony," stating that "such a rule

28. In later extra-court discussions, Judge Curtis Bok expressed and authorized me to state his own opposition, on theoretical and practical grounds, to the imposition of liability for murder in the first degree in cases like Wilson. He directed the jury in these terms in Wilson because of the ambit of the decision of the Supreme Court in Almeida and in the hope that, should the jury convict, the Supreme Court on appeal would reconsider and narrow the rule adumbrated in Almeida.

29. In Pennsylvania, when returning a conviction of murder in the first degree, the jury has a discretion to decide whether the penalty shall be death in the electric chair or life imprisonment. In Wilson, the District Attorney told the jury that he was not asking for the death penalty, and Judge Bok, in his charge, stressed this and expressed his opinion that if they convicted Wilson, "I think ... you would follow the recommendation of the District Attorney for life imprisonment."

30. No. 1487, Philadelphia County Ct. Oyer \& Terminer, Dec. 13, 1954 (Charles L. Guerin, J.).

31. "The felon's robbery set in motion a chain of events which were or should have been within his contemplation when the motion was initiated. He therefore should be held responsible for any death which by direct and almost inevitable sequence results from the initial criminal act. ... For whatever results follow from that natural and legal use of retaliating force the felon must be held responsible." $382 \mathrm{~Pa}$. at 642 , 117 A.2d at 205. 
is equally consistent with reason and sound public policy, and is. essential to the protection of human life." 32

The opinions reflect a heatedly divided court. The cleavage between the majority and Justices Jones, Chidsey and Musmanno follows the same lines as emerged in Almeida, but is emphasized by the concurring opinion of Justice Bell who sought to controvert the dissenters point by point. Two further leading cases and one further issue were canvassed. The latter was most forcefully advanced by Justice Musmanno in dissent and may be summarized as follows: the killing of Jackson by Cecchini was justifiable homicide, and "the whole theory of the criminal law is to punish for what should not have happened. . . . How can anyone be punished for what the law required. . . . Should the courts be placed in the preposterous situation of trying a murder case where no murder was committed?" 33 It is submitted that this type of distinction between Almeida and Thomas, by which the former is a murder because an innocent policeman was killed while the latter is not because the shopkeeper had a legal right to shoot Jackson, is unsupportable even though it has some emotional attraction. Cecchini's justification is personal to him. It does not insulate from conviction others accessorially or causally responsible for that killing. There is authority and theoretical support for the conviction of those who have acted through innocent agents, through the insane and through those who have diplomatic immunity or immunity based on age or duress. In these cases the hand which effects the crime is not visited with criminal liability; but the mind or conduct of another behind that hand is liable. ${ }^{34}$

Another doubtful differentiation between Almeida and Thomas was sought in the fact that in Thomas and Wilson, as contrasted with Almeida, it is a co-felon who is killed. The co-felon does not, by embarking on the felonious enterprise, put himself outside the protection of the criminal law; one may not with impunity steal from a thief nor murder a murderer as he is in the act of committing his crime. Nor does the volenti non fit iniuria principle accord well with the ethos of the criminal law, even though the surviving co-felon's alleged liability for murder is based on a concept of foreseeability of the consequences of a felonious act which the deceased must be held to share. Whether or not it is possible to draw a valid distinction along

32. Ibid.

33. Id. at $685,117 \mathrm{~A} .2 \mathrm{~d}$ at $224-25$.

34. See the discussion of these types of cases in Williams, Criminal LawThe Genkral Part 178-80, 210-13 (1953). 
these lines is not at present my concern; it will be submitted that Almeida and a fortiori Thomas were unwise and unnecessary decisions and therefore the possible volenti distinction between them does not demand attention.

The dissent by Justice Jones, in which he reaffirms his view that "in order to convict for felony-murder, the killing must have been done by the defendant or an accomplice or confederate or by one acting in furtherance of the felonious undertaking," ${ }^{35}$ and its attempted rebuttal by Justice Bell are essentially reiterations of the positions assumed in Almeida-with the main exception that People v. Ferlin ${ }^{36}$ and the conflicting case of Commonwealth $v$. Bolish ${ }^{\mathbf{3 7}}$ were also canvassed. In the former, the Supreme Court of California reversed the defendant's conviction of murder for the death of his co-felon who accidentally killed himself in the course of perpetrating their agreed felony, arson; in the latter the Supreme Court of Pennsylvania held that in similar circumstances the accused should be so convicted. ${ }^{38}$

Hence, as the Pennsylvania rules now stand, if $A$ and $B$ are together involved in the felonies of arson, rape, robbery, burglary or kidnapping and, as a consequence of their actions or the actions of others set in motion by their felony, one of them or someone else is killed, they (or their survivor) may be convicted of murder in the first degree. Though purportedly compelled by authority, the policy reasons for the majority's view of the law is stated in the concluding words of Justice Bell in Thomas: "For the protection and welfare of the people of this Commonwealth, the public and the Courts must stop coddling criminals, young as well as old, otherwise the terrible brutal crime wave which is sweeping our State and Country will never be halted." 39 If this development or extension of the felony-murder rules is to be used in other jurisdictions ${ }^{40}$ as a weapon in the war on crime it demands careful consideration, both as to its potential strategic and

35. $382 \mathrm{~Pa}$. at $664,117 \mathrm{~A} .2 \mathrm{~d}$ at 215.

36. 203 Cal. 587, 265 Pac. 230 (1928).

37. $381 \mathrm{~Pa} .500,113$ A.2d 464 (1955).

38. The conflict between these two cases is discussed at pp. 78-81 infra.

39. $382 \mathrm{~Pa}$. at $659,117 \mathrm{~A} .2 \mathrm{~d}$ at 213.

40. From the reports it would appear that up to and including 1922 all cases in this general field denied liability; that between 1922 and 1935 was a period of vacillation; and that all cases in which the issue has arisen since the 1935 decision in People v. Payne, 359 IIl. 246, 194 N.E. 539 (1935) have accepted the imposition of liability on the grounds of causation where the defendant knew that forceful resistance could be expected. The jurisdictions already involved are Illinois, Michigan and Pennsylvania. See People v. Podolski, 332 Mich. 508, 52 N.W.2d 201 (1952). Recently the Supreme Court of Florida, though not faced squarely with this issue, expressed its approval of Almeida. Hornbeck v. State, 77 So. 2d 876, 878 (Fla. 1955). 
tactical value and as to the instrumentality of the state which is to be responsible for adopting it. ${ }^{41}$

\section{Felony-Murder, Causation and Mens Rea}

A somewhat dogmatic review of the felony-murder rule may provide a fresh approach to the problem. In Lord Dacre's case ${ }^{42}$ appears what is probably the first formal statement of the rule. ${ }^{43}$ Here it is used as a technique of attributing the particular malice required for a conviction of murder, malice prepense (or, later, malice aforethought), to one co-felon for the murderous act of another co-felon. It develops in its formulations through Coke, ${ }^{44} \mathrm{Hale},{ }^{45}$ Foster, ${ }^{46}$ Blackstone ${ }^{47}$ and East ${ }^{48}$ to Stephen's expression of hostility to the rule he felt compelled to accept, ${ }^{49}$ until its modification in England by the decision in Director of Public Prosecutions v. Beard ${ }^{50}$ which allowed "malice aforethought" to be irrebuttably established by proof that the death occurred from "an act of violence in the course of or in furtherance of a felony of violence." 51 Most jurisdictions of the United States accept the common law felony-murder rules-less the later Beard gloss-as distinguishing murderous homicides from those not subject to such a high degree of criminal liability, but such acceptance has been extensively modified by various statutory provi-

41. A problem of proof also arises. In Almeida, Wilson and Thomas it was agreed that the lethal acts were legally justified acts of resistance to the felonies. If such an act were excessive and not justified by the threat of the felony or the need to prevent an escape, presumably (though not certainly, so wide are some of the statements of the courts in these cases) the felon would be insulated from liability for the killing. If this be so, on whom lies the burden of proof that the lethal act was legally justified? Must the accused establish that it was not or is it sufficient if he raises "some evidence" to this effect? The danger is that the form of the proceedings will raise a presumption that the person resisting the felony, or the policeman endeavouring to effect an arrest, was justified in his use of lethal force. This presumption will be hard for the admittedly felonious accused to rebut.

42. Moore 86, 72 Eng. Rep. 458 (K.B. 1535).

43. The rule was probably borrowed from the Roman-law doctrine of versari in re illicita. There is, indeed, more than a hint of the existence of such a rule in Bracton's De Legibus et Consuetudinibus Angliae (1256 ?). In discussing unintended, chance deaths and homicide he writes, "But here it is to be distinguished whether a person is employed upon a lawful or unlawful work," the death being "imputed to his account" in the former instance while in the latter, if due care has been taken, "blame is not imputable to him." 2 BRAcron, DE LEgibUS ANGLIAE ET ConsuerudinIBUS ANGLIAE, 277 (Twiss ed. 1879).

44. 3 Coke, Instrtutes 56 (1797).

45. 1 Hate, Pleas of the Crown 424-503 (1st Am. ed. 1847).

46. Foster, Crown Cases and Crown Law 256, 258, 308 (3d ed. 1792).

47. Biackstone, Commentarues $\S \S 192-93,200-01$.

48. 1 East, Pleas of the Crown 255 (1896).

49. 3 Stephens, A History of the Criminal Law of England 57, 75 (1883).

50. [1920] A.C. 479 .

51. Id. at 504. An excellent summary of the development of "malice aforethought" in England and Scotland is to be found in Royal Commission on Capital Punishment, Report, CMD. No. 8932 (1953). 
sions. $^{52}$ Nevertheless, for a majority of jurisdictions in the United States this rule still forms an integral part of the law. Its original and present effect is the imputation of a certain state of mind, the mens rea regarded as essential to liability for murder, to one who may or may not in fact have had that intention. The classic mens rea of murder is an intention to kill; this is extended to include an intention to do an act intrinsically likely to kill, possibly formulated sufficiently by an intention to inflict grievous bodily harm. An intention to inflict physical hurt is involved in all versions. ${ }^{53}$ Superimposed is the further concept that if the death occurs in the course of certain felonies, differently described in different jurisdictions, the particular malice required for murder will be held to exist. ${ }^{54}$ The accused in these cases will be treated as if the particular type of malice required for murder existed. The phrase used in English cases and by English commentators, "constructive murder," captures the essence of this rule. ${ }^{55}$ The felony-murder rule is thus a rule for establishing the mens rea of murder; it is not a rule of causation, it does not bear upon the actus reus of homicide.

52. Only eight states have statutorily accepted, for purposes of first degree murder, the earlier common-law definition of felony-murder as a homicide occurring in the commission of any felony. Kan. Gen. Stat. ANN. \$21-401 (1949); MinN. Stat. \$619.18 (1949); N.M. STAT. ANN. \$ 40-24-4 (1953); N.Y. PEN. LAW § 1044 ; N.C. Gen. STAT. \$ 14-17 (1953); N.D. REv. Code \$12-2708 (1943); OkrLa. Stat. tit. 21, § 701 (1951); S.D. REV. CoDE \& 13.2007 (1939). North Dakota, however, requires that the felony be statutorily defined as such. Three states have no specific statutory provisions regarding felony-murder; these are Kentucky, South Carolina and Maine. (The latter state having, however, extended the common law to cover statutory rather than common-law felonies. Smith v. State, $33 \mathrm{Me}$. 48 (1851).) The remaining jurisdictions have statutes in which specific felonies are enumerated. Most numerous among these are arson, rape, robbery and burglary; others are poisoning, mayhem, kidnapping, sodomy, jailbreak and the use of explosives with the intent to injure persons or property. Three states include larceny in the enumeration of felonies (ARK. STAT. \$41-2205 (1947); TENN. CODE ANN. \$39-4202 (1956); WASH. REv. CODE $\$ 9.54 .090$ (1955)). Massachusetts (MASS. GEN. LAws c. 265, § 1 (1932)) and Delaware (DEL. CODE ANN. tit. 11, §571 (1953)) require that the felony be punishable by death to be encompassed by the doctrine, while the District of Columbia (D.C. CODE ANN. \$22-2401 (1951)) requires that the crime carry punishment of imprisonment in the penitentiary. It is held, however, that the fact that the felony being committed is not among those enumerated in the statute does not prevent the homicide from being murder; it is simply murder of another degree. Kinsey v. State, 49 Ariz. 201, 65 P.2d 1141 (1937). On the Illinois position, see Comment, Proposed Revisions in the Illinois Criminal Code, 48 Nw. U.L. REv. 198, 213-14 (1953). See the discussion of statutory modification of the felony-murder rule in Moesel, $A$ Survey of Felony Murder, 28 TEMP. L.Q. 453 (1955).

53. The problems of general malice and transferred malice are not here relevant. However, they do not conflict with this analysis.

54. Later still than the development of constructive murder through the felonymurder rules, there emerges in some jurisdictions another constructive doctrine of imputing the necessary mens rea of murder to one who uses violence in resisting lawful arrest and kills in doing so.

55. "Malice aforethought" is here imputed even though it may not actually have existed in respect of the harm which has occurred. It is imputed by means of a wellestablished legal fiction. Until the decisions considered in this article, this fiction was limited to cases in which an intent to kill may or may not have existed but in which it might have existed. In the Pennsylvania cases, the fiction is sought to be applied 
Historically and at present, if $A$ kills $B, A^{\prime} s$ act is a culpable homicide, either murder or manslaughter, unless he is justified or excused in his action. An accidental or unintentional act may well be neither justifiable or excusable. Nevertheless, justifications or excuses serve to exclude certain homicides from the area of culpable homicides; a culpable homicide once established, the felony-murder rule may or may not apply. It should not be applied before this stage since it is not a rule of causation and does not bear upon the actus reus of homicide. Yet that is one of the uses to which the majority in Almeida and Thomas put it. In the latter case, Justice Bell cites Blackstone's statement ${ }^{56}$ of the rule and offers this explanation of its rationale:

"The reason is that (a) any person committing any common law felony or one of the enumerated statutory felonies, possesses a malevolent state of mind which the law calls 'malice'; and (b) malice is present in the felon (or felons) actually or by legal implication not only at the time of the original felony but also at the time of the killing; and (c) such person is from time immemorial responsible for the natural and reasonably foreseeable results of his felony." 57

To this it can be answered, the mens rea or "malice" necessary for the felony is in every instance different from the mens rea or "malice aforethought" required for murder; but for certain killings the law will allow the latter to be conclusively proved from the former. This is not to identify them at all-it is merely to say that in certain cases proof of the particular state of mind required for murder will be established by the mens rea of certain felonies; it will be malice "implied" rather than "express." The difference is significant for it preserves the

to cases where an intent to kill demonstrably did not exist. This is a perverse use of the device of legal fiction. The Commissioners of the Criminal Code Bill of 187879 , in noting their opposition to the felony-murder rule, commented: "In this case as in the case of other legal fictions it is difficult to say how far the doctrine extended. ... It seems to us that the law upon this subject ought to be freed from the element of fiction...." Criminal Code BILl Comimission, Report 23-24 (1879). On the logical dangers involved in legal fictions, see 7 BENTHAM, WorKs 283-87 (1843), reprinted in OgDen, Bentham's TheORY of Fictions app. A (1932).

56. See note 47 supra.

57. $382 \mathrm{~Pa}$. at $646,117 \mathrm{~A} .2 \mathrm{~d}$ at 207 . To like effect is the statement of Chief Justice Maxey, delivering the judgment of the court in Almeida: "The reason is that any person committing or attempting to commit any of these major felonies is motivated by malice and when the killing of a human being directly results, even though not intended, from his malicious act, it is murder because malice, the essential element of murder, is present." $362 \mathrm{~Pa}$. at 625,68 A.2d at 609 . Accord, Commonwealth v. Guida, $341 \mathrm{~Pa}$. 305, 19 A.2d 98 (1941): "The common law rule. . was that if a person killed another in doing or attempting to do another act, and if the act done or attempted to be done was a felony, the killing was murder. There was thus supplied the state of mind called malice which was essential to constitute murder. The malice of the initial offense attaches to whatever else the criminal may do in connection therewith." Id. at 308,19 A.2d at 100 . 
felony-murder rules as a mens rea-imposing mechanism and avoids the reification of malice revealed in Justice Bell's statement. Proposition (c) is false if it is meant to imply, as it would seem to, that a felon has from time immemorial, because of the "malice" of his felony, been responsible for more than his own acts or those of his co-felon in pursuance of the felony. Not until Almeida ${ }^{58}$ is responsibility more widely cast than this.

This point is central to the criticism of the retaliatory force decisions. In Commonwealth v. Bolish, Justice Bell reiterated his unitary conception of "malice":

"Malice express or implied is the criterion and absolutely essential ingredient of murder. Malice in its legal sense exists not only where there is a particular ill will, but also whenever there is a wickedness of disposition, hardness of heart, wanton conduct, cruelty, recklessness of consequences and a mind regardless of social duty. . . . If there was an unlawful killing with (legal) malice, express or implied, that will constitute murder even though there was no intent to injure or kill the particular person who was killed and even though his death was unintentional or accidental." 59

In other words, "malice," the mens rea of murder, is identical with "malice," the mens rea of larceny-which is absurd. Further, if Justice Bell's statement is to be accepted, the difference between involuntary manslaughter and common law murder entirely disappears. At least some of the conditions, wickedness of disposition, hardness of heart, wanton conduct, cruelty, recklessness of consequences and a mind regardless of social duty, will be present in all involuntary manslaughter cases, and the killing will always be unlawful; on his analysis of "malice," murder is the appropriate verdict. It is the typical semantic error; it is assumed that to each word there is but one referent.

Once this reification of malice is avoided, the historical distinction between the felon's responsibility for the unintended or accidentally lethal acts of himself or his co-felon and his liability for lethal acts (though naturally and reasonable foreseeable) of those resisting the felony may be preserved. He is guilty of murder for his (or his co-felon's) unintended and accidentally lethal acts because such killings are neither justifiable nor excusable, the actus reus of homicide is present and the law has for centuries, rightly or wrongly, imputed to

58. Apart from the "shield" cases and the "alternative danger" cases discussed hereunder.

59. $381 \mathrm{~Pa}$. at $511,113 \mathrm{~A} .2 \mathrm{~d}$ at 470 . 
such acts the malice required for murder. ${ }^{60}$ It has not, until Almeida, done this for the lethal acts of others set in motion by the felon's acts. Innumerable opportunities to take this step existed before Almeida. Provided the error is not made of regarding "malice" as a single concept pervading certain felonies and murder alike, there is no logical reason why the felony-murder rule should be extended in this way.

To achieve this widening of the imputation of the imens rea of murder to cover acts of others where no killing was intended or desired by the felons, the Pennsylvania Supreme Court in Almeida and Thomas sought authority in three types of cases.

First, they relied on cases of accidental killings in the course of a felony in which the felon or his co-felon performed the lethal act. ${ }^{\text {.1 }}$ In these cases the felony-murder rule operated frequently as a fiction, if intention to kill is the characteristic of murder. It cannot be argued that these cases compelled the extension of the fiction to cases where the lethal act was not the felon's or his co-felon's.

60. See Perkins, A Re-Examination of Malice Aforethought, 43 YALE L.J. 537 (1934), in which the technical and distinct nature of "malice aforethought" is demonstrated.

61. Johnson v. State, 142 Ala. 70, 38 So. 182 (1904) (defendants assisted their father in violently resisting arrest during which he shot a police officer); State v. Leopold, 110 Conn. 55, 147 Atl. 118 (1929) (Arson of house; two boys trapped therein and killed. Felons convicted of murder even if the children could have escaped apart from their own stupidity or their father's dangerous conduct. This case shades off into the "alternative danger" type of case, hereunder.) ; Spies v. People, 122 Ill. 1, 12 N.E. 865 (1887) (Chicago "anarchists" case; bomb thrown by one who was held by inference to be co-conspirator with accused) ; Commonwealth v. Lowry, $374 \mathrm{~Pa}$. 594, 98 A.2d 733 (1953) (driver of getaway car responsible for killing by his co-felon in course of robbery) ; State v. Hauptmann, 115 N.J.L. 412, 180 At1. 809 (1935) (defendant could be convicted of murder if he accidentally killed the infant by allowing it to fall when climbing out of a window and down a ladder carrying the child in the process of abducting it) ; Commonwealth v. Hare, 2 Pa. L.J. Rep. 467 (1844) (Innocent bystander killed by shot from one of two groups of men fighting each other with firearms. All members of both groups could be convicted of murder. The principle here applied is that members of both groups are treated as if they were felons. The case is not one of retaliatory or defensive force to a felony; the impossibility of deciding from which group the shot was fired and the fact that all were involved in the same wrong were determinative.); Regina v. Towers, 12 Cox C.C. 530, 533 (Ct. Crim. App. 1874) (defendant frightened infant in mother's arms from which infant died).

Commonwealth v. Moyer, $357 \mathrm{~Pa}$. 181, 53 A.2d 736 (1947) causes some difficulty. Judicial statements therein support the majority's decisions in Almeida and Thomas, the Pennsylvania Supreme Court being prepared to uphold the conviction on the hypothesis that the killing of the innocent bystander was murder by the felons, whether or not it was a result of a shot from their guns or from the gun of the proprietor of the premises being robbed. However, the case was left to the jury on the assumption, and with the direction to convict only if they were satisfied beyond a reasonable doubt, that one of the felons fired the fatal shot. The statement on appeal must then be regarded as dicta. Even if this be erroneous, as Justice Bell contends in Thomas (see $382 \mathrm{~Pa}$. at $652 \mathrm{n} .4,117 \mathrm{~A} .2 \mathrm{~d}$ at $210 \mathrm{n} .4$ ), it only shifts the whole inquiry into the merits of this development of the common-law principles back to 1947, for Moyer, like Almeida and Thomas, is a decision of the Pennsylvania Supreme Court. Several other cases where a felon was convicted of murder in the first degree for a killing by his co-felons in furtherance of the felony were cited; they create no difficulties of analysis and accord with the categorization in the text. 
The second group is the "shield" cases, ${ }^{62}$ where liability is fixed on the accused because of his act of direct and deliberate creation of immediate lethal danger to the deceased and to him alone. The malice is express rather than implied, and the analogy with liability for deaths arising from the danger of retaliatory force is not compelling.

Third, they relied on cases where the victim of a felony, or of an otherwise murderous act, in an effort to escape the danger or minimize the loss from the felony, caused his own death. ${ }^{63}$ Again there was an intentional felonious or killing act directed by the accused at the deceased, and there is no compulsion to apply the ratio of these cases-the alternative-danger-in-an-emergency concept, ${ }^{64}$ by which the accused is criminally responsible for the acts of the deceased seeking to avoid the danger to him which the accused has createdto the problems of death flowing from retaliatory force.

In all these cases, which include all the authorities advanced by the court in Almeida and Thomas in support of their decision on this essential point, ${ }^{65}$ the accused or his co-felon has in fact either selected the victim or victims of his murderous or felonious acts, and it is his liability for their death which is being considered, ${ }^{66}$ or he or his co-

62. See cases cited in note 24 sipra and the comment on the rationale of these cases at note 26 supra.

63. People v. Manriquez, $188 \mathrm{Cal} .602,206 \mathrm{Pac} .63$ (1922) (Victim of holdup grappled with felon and in struggle was shot by felon's gun. Murder even if actual physical force of victim fired the gun.) ; Letner v. State, 156 Tenn. 68, 299 S.W. 1049 (1927) (Defendant shot at three men in boat. In endeavoring to escape, one of them jumped out of the boat, causing it to capsize. He and another drowned. A conviction of manslaughter was upheld.); Queen v. McIntyre, 2 Cox C.C. 279 (York Assizes 1847) (This case falls into either the first or second group of cases. Defendant kicked his wife on the throat and elsewhere. Physician administered brandy as restorative. The brandy entered her lungs and killed her, the kick having caused the defective power of swallowing. The death can either be regarded as flowing from the defendant's lethal act or, if the link between the felonious act and death be regarded as more remote than this, as being caused by a third party's effort to minimize the danger to a victim of a felony. On either view, the case is well-removed from the defensive and retaliatory force situations, for the defendant has here selected for violent assault the person who is killed.) ; Rex v. Hickman, 5 Car. \& P. 151, 172 Eng. Rep. 917 (N.P. 1831) (Defendant assaulted deceased who was on horseback. Deceased spurred horse to escape. Horse threw and killed him.) ; Rex v. Valade, 26 Can. Crim. Cas. Ann. 233 (K.B. 1915) (Defendant took girl to room for immoral and felonious purposes. In endeavoring to escape, she killed herself. Conviction of manslaughter.). In Rex v. Hickman, supra the court relied upon Rex v. Evans, Old Bailey 1812, cited in RUSSELL, CRIME 469 (10th ed. 1950) (conviction of murder directed if the jury believed that the accused assaulted his wife and that as a result of the assault she jumped out of the window to escape from him and thus killed herself).

64. Lord Coleridge, in Regina v. Halliday, 61 L.T.R. (n.s.) 701, 702 (Crown Cas. Res. 1889), stated this concept as follows: "If a man creates in another man's mind an immediate sense of danger which causes such person to try to escape, and in so doing he injures himself, the person who creates such a state of mind is responsible for the injuries which result."

65. In Thomas, the decision in Commonwealth v. Bolish, $381 \mathrm{~Pa} .500,113 \mathrm{~A} .2 \mathrm{~d}$ 464 (1955), where a co-felon in arson accidentally kills himself, was discussed. This case is considered at pp. 78-81 infra. It falls into the group of felony-murders where the felon or co-felon performs the directly lethal act.

66. The general malice and transferred malice doctrines would require a wider statement of this proposition for complete accuracy, but they do not detract from the force of the contrast suggested in the text. 
felon has performed the directly lethal act; ${ }^{87}$ in the retaliatory force situations in Almeida, Wilson and Thomas, neither of these conditions apply.

On this analysis it is no overstatement to conclude that the majorities in Almeida and Thomas were neither historically nor analytically justified in their decision; that the dissenters in these cases were not demonstrably in error; and that these cases constitute an extension of the felony-murder rule, an extension whose social utility and justice remain to be considered.

Before inquiring into the purposes thought worthy of pursuit in this wider application of the felony-murder rule, two subsidiary questions merit consideration. What is the relationship between the common-law felony-murder rule and the relevant Pennsylvania statute? And could the defendants in Almeida, Wilson and Thomas have been convicted of manslaughter?

\section{Common-Law Felony-Murder and Its Statutory Formulation}

The Pennsylvania Penal Code provides ${ }^{68}$ that:

"All murder which shall be perpetrated by means of poison, or by lying in wait, or by any other kind of willful, deliberate and premeditated killing, or which shall be committed in the perpetration of, or attempting to perpetrate any arson, rape, robbery, burglary or kidnapping, shall be murder in the first degree. All other kinds of murder shall be murder in the second degree ...."

Thus the crime of murder is defined in Pennsylvania by the common law, and the statute merely declares certain types of murders to be first degree. This is accepted in the majority and minority opinions in Almeida and Thomas. Yet by combining the felonymurder rules and the proposition that the law of causation is the same in crime as in tort, the majority in effect use the felony-murder rules twice: once as a method of saying that because the death was a reasonably foreseeable result of the emergency created by the felonious act the crime is murder, and again, in its statutory form, as declaring that murder to be first degree. When a statute is drawn in this form, this double application of the common-law felony-murder rule and the statutory rule of felony-murder in the first degree is appropriate; but there is the danger that the rule, when so applied, will be used not

67. Provided it be agreed that it is a lethal act to compel a person to act as a shield against bullets or as a shield in the hope of preventing bullets being fired. The justification of conviction of murder in these "shield" cases is to be sought more in the compulsion exerted on the "shield," which is itself an act intrinsically likely to kill, rather than within the ambit of the felony-murder rule.

68. Pa. Stat. AnN. tit. 18, \$4701 (Purdon 1939). 
to impute malice but rather, and incorrectly, to impute the act of killing. At all events, the statute certainly does not compel the decisions in Almeida and Thomas. ${ }^{69}$

The Pennsylvania statute was enacted in substantially its present form in $1794{ }^{70}$ and served as a model for similar legislation in many other states. When reference is made to the preamble of the 1794 statute, the decisions in Almeida and Thomas appear as Gilbertian exercises in statutory interpretation:

"Whereas the design of punishment is to prevent the commission of crimes, and repair the injury that hath been done thereby to society or to the individual, and it hath been found by experience that these objects are better obtained by moderate but certain penalties, than by severe and excessive punishments: And whereas it is the duty of every government to endeavor to reform, rather than exterminate offenders, and the punishment of death ought never to be inflicted, where it is not absolutely necessary to the public safety . . . " 71

It is clear that the statute's purpose was clemency, the careful gradation of harms and the reservation of the gravest punishment for the gravest harms-purposes hardly served by Almeida and Thomas.

\section{Retaliatory Lethal Force and Manslaughter}

A man is liable for involuntary manslaughter, unless his act can be otherwise justified or excused, if his lawful or unlawful act causes death and that act was recklessly performed by him despite a high and foreseeable risk of death to other persons. This formulation of manslaughter liability for deaths produced by grossly reckless conduct, particularly where that conduct is also criminal, might well be urged to include the conduct of Almeida, Wilson and Thomas. Certainly there is as much, indeed more, to be said for the conviction of these accused persons of manslaughter than there is for their conviction of murder, and less violence would thereby be done to established doctrine. The killings are neither justifiable nor excusable and are causally linked to their felonious actions, and the reality of the situation

69. The New York statutory definition of felony-murder, N.Y. PEN. LAw § 1044, differs from the Pennsylvania statute in that it refers to a certain class of "killing" as being murder in the first degree and only a killing "by a person" engaged in the felony. It reads: "The killing of a human being . . . is murder in the first degree, when committed .... by a person engaged in the commission of, or in an attempt to commit a felony, either upon or affecting the person killed or otherwise...." Basing its position on these differences in the statutory provisions, the court in Almeida distinguished certain dicta in People v. Udwin, 254 N.Y. 255, 172 N.E. 489 (1930), which were contrary to its decision in Almeida.

70. 3 LAws of PA. c. $1746, \S \$ 1,2$ (1794).

71. 3 id. at 186. 
is that they have consciously and deliberately risked injury and death for all those imperiled by the foreseeable retaliatory force they have set in motion. This is exactly the type of harm involuntary manslaughter is intended to proscribe.

The misdemeanor-manslaughter rule, in its present application virtually only to misdemeanors where risk of bodily harm to others is involved, ${ }^{72}$ is not necessary to the liability suggested above. Nevertheless, its rationale buttresses the force of the suggestion that if policy considerations do not justify the larger step taken in Almeida and Thomas, they may nevertheless justify convicting of manslaughter persons whose criminal conduct unleashes foreseeably lethally-dangerous retaliatory force. ${ }^{73}$

If the argument advanced earlier is accepted-that liability for murder in these cases involves more than mere proof of the existence of some felonious intent plus causal relationship between the felony and the death-there is no lack of logic in rejecting a conviction of murder in these cases and accepting a conviction of manslaughter. Whether it is desirable to increase at all the punishment for the felony itself because of the result of force opposing it is, of course, a central issue yet to be considered.

\section{Policy Considerations}

It is much easier to seek to justify one's prejudices by an emotional appeal than it is to support them with socially meaningful and methodologically defensible propositions. Yet at least some of the facts are clear on this issue-for centuries innocent persons and felons have been killed as the result of justified resistance to felonies of violence; in only a handful of such cases has it been even suggested that the surviving felons are guilty of murder. When felony itself was punished by death there may have been little utility in testing this issue, yet the existence of benefit of clergy ${ }^{74}$ must often have made it literally a vital question for the criminal. Further, any reading of early English

72. "Homicides resulting from unlawful acts were manslaughter subject to the single qualification which early appeared, that the unlawful act be malum in se. In the course of time the same impetus was felt as in the case of felony-murder, to narrow this category to cases where the unlawful act was dangerous to life. This was accomplished more successfully than in the case of felonies in similar ways, by defining malum in se so as to include misdemeanors dangerous to life or limb and exclude non-dangerous misdemeanors, or by introducing the factor of danger by means of a requirement of proximate causation." Wechsler \& Michael, $A$ Rationale of the Law of Homicide, 37 Colum. L. REv. 701, 722 (1937).

73. In most jurisdictions, manslaughter carries a heavier maximum penalty than most felonies and attempted felonies. But apart from this, if a conviction of a homicide in these cases is thought to have social utility, manslaughter is the category of homicide which most closely reflects the harm that the criminal has encompassed.

74. Originally only members of the clergy but later any literate male might escape capital punishment for his first homicide by "pleading his clergy." See 1 STEPHEN, op. cit. supra note 49 , at 461 . 
authorities on homicide reveals that this type of issue was not likely to be avoided by the courts or the prosecuting authorities if the offense were seriously thought to be murder. For example, the case of Plummer, considered later in this article, ${ }^{75}$ was, in the first year of the eighteenth century, retained under the advisement of all the judges of the King's Bench for a period exceeding a year during which time it was extensively debated in private and public; it concerned just such a situation, where the accused was admittedly guilty of a capital felony and was eventually held not guilty of murder.

It can be concluded, especially in jurisdictions where the police and many private citizens carry arms, that there is no lack of cases ${ }^{76}$ to which the application of this wider definition of murder would be germane. Since this has not been done, it would appear that we are fashioning a new weapon. What is our aim in so doing? Deterrence must be the main purpose; it is the purpose expressed by the majority in Almeida and Thomas. Here one can but speculate, and speculate skeptically. The whole theory of the deterrence of serious crimes by variations in the weight of the punishment imposed on the perpetrators is so much in doubt as to make rational judgment on the effect of this particular increased punishment doubly dubious. Furthermore, where it is sought to increase the deterrent force of a punishment, it is usually accepted as wiser to strike at the harm intended by the criminal rather than at the greater harm possibly flowing from his act which was neither intended nor desired by him; that is to say, for the situations before us, to increase penalties on felonies-particularly armed felonies-wherever retaliatory force can be foreseen, rather than on the relatively rarer occasions when the greater harm eventuates. ${ }^{77}$

Reason and such experience as exists in this field would suggest that Almeida and Thomas, if their purpose be the increase of the infra.

75. Rex v. Plummer, Kel. 109, 84 Eng. Rep. 1103 (K.B. 1700?); see pp. 69-71

76. That there have been three cases (including Commonwealth v. Bolish, 381 Pa. 500, 113 A.2d 464 (1955)) in Pennsylvania since the Almeida decision and none in other jurisdictions indicates that it is the interest of the prosecuting authorities in this previously ignored possible extension of the crime of murder, rather than a sudden chance statistical flowering of this type of death, which brings this issue before the courts.

77. As a general proposition it is submitted that the statutorily authorized and judicially implemented application of substantially heavier punishments on all felons carrying a gun at the time of their felony (or taking part in a felony where a cofelon used a gun in furtherance of the felony) would better serve the purpose of deterring the type of conduct in Almeida and Thomas than do the decisions in those cases. Some jurisdictions have provided for such higher penalties, but there would appear to be a reluctance on the part of the courts to impose wholeheartedly these heavier penalties. In England and other countries of the British Commonwealth, particularly where the police are unarmed, such a policy is deliberately followed by the courts. The general opinion in these countries is that there is wisdom in this course. The essential harm is that the felon carries or uses a gun-let us fasten upon that with the utmost severity. 
deterrent effect of punishment, are striking at the wrong thing-at the fact of a death rather than at the fact of a felony of a certain type which risks a death. ${ }^{78}$

If the justification be one of vengeance, of just retribution for a fearful harm, the community as a whole does not in all probability regard that harm as meriting its gravest punishment (whether or not it be capital punishment) which is reserved for what has been traditionally regarded as murder in the first degree, i.e., for intentional killings and for killings of the victims of felons in pursuit of their felonious purposes. To declare Almeida's and Thomas' conduct to be murder weakens the force and gravity of that finding for appreciably graver offenses. ${ }^{79}$ If aggravation of punishment for the felony itself be thought necessary, consideration should be given to the desirability of charging criminals in these situations with manslaughter. This would do less violence to established doctrine and would more accurately reflect the harm that the criminals have encompassed.

Finally, if the view be that justice and social utility are to be served by imposing on felons criminal liability for murder where the killing is the result of defensive and retaliatory force that they have precipitated, it is submitted that this is a step more appropriately to be taken by the legislature than by the judiciary. Admittedly, the problem is technically one of the interpretation and application of a common-law rule, a typically judicial task, but the force of a host of sub silenti precedents runs counter to such a novel development. Over at least three centuries, many deaths which could have been treated as murders under this interpretation of the felony-murder rule have not been so treated. Such is the state of the authorities and such the force of visceral reactions to this problem that if this development of the law

78. "To punish as a murderer, every man who, while committing a heinous offence, causes death by pure misadventure, is a course which evidently adds nothing to the security of human life. . . The only good effect which such punishment can produce will be to deter people from committing any of these offences which turn into murders what are in themselves mere accidents. It is in fact an addition made in the very worst way. ... If the punishment for stealing from the person be too light, let it be increased, and let the increase fall alike on all the offenders! Surely the worst mode of increasing the punishment of an offence is to provide that, besides the ordinary punishment, every offender shall run an exceedingly small risk of being hanged." CoMmissioners on CRIMINAL LAw, SECOND REPORT 17 (1846), quoted in I Russeli, CrIme 563 (10th ed. 1950).

79. I am informed that despite the majority decision in Thonas, reversing the trial court's acceptance of the defendant's demurrer and ordering a re-trial, the prosecuting authorities do not propose to put Thomas on trial for murder. To what extent is it their desire to settle a nice point of law and to what extent is it to convict and punish for murder criminals in Thomas' position? In Wilson the death penalty was not sought. Without murder findings, Almeida, Wilson and Thomas could be held in prison for anything up to twenty years. PA. Stax. ANN. tit. 18, §4705 (Purdon 1939). 
be thought desirable it should be effected by the legislature; the judiciary should not conjure it from the common law.

\section{Collateral Lethal Force}

Let us turn from considering the felon's liability for lethal acts by his victim or the police to his liability for lethal acts by his co-felon.

The received doctrine is that an accessory before the fact or a principal in the second degree is liable for the commission of a crime different from the one instigated or agreed upon if the crime committed was "likely to be caused by such instigation." 80 There are several different formulations of this concept, some turning liability on the reasonable foreseeability of the commission of the second crime, some requiring that the second crime should be "closely related" to the planned commission of the first crime, but all involving the idea of the crime actually committed being "within the risk" of the crime planned. When the facts compel this doctrine to be related to the felony-murder rule, difficulties of analysis obtrude which have produced an absolute conflict between recent California and early English authority.

In 1701 at the Kent Assizes, Benjamin Plummer was tried for the murder of John Harding. ${ }^{81}$ The jury found a special verdict which, prior to its decision, was held for two vacations under the consideration of all the judges of the King's Bench, and which was several times argued at Searjeants Inn in Chancery Lane. The facts were summarized by Chief Justice Holt as follows:

"Eight persons had loaded a quantity of wool to carry it to be transported [to France, which was illegal]; of which the King's officers having intelligence, did in the night time, as they were carrying the wool, meet to oppose, and to apprehend them, and they met in a lane, and upon a watch word given by the King's officers, one of the eight persons shot off a fuzee, and killed another of the eight persons, whether the others of the eight (beside him that shot off the gun) be guilty of the murder of the person slain?" 82

Plummer was one of the conspirators, Harding another. Plummer did not fire the shot which killed Harding. The shot was not discharged by accident but was fired deliberately by another conspirator.

Chief Justice Holt announced an agreed verdict of not guilty on the following reasoning:

80. Staphein, A Digest of THE CRIminal Law 20 (9th ed. 1950).

81. Rex v. Plummer, Kel. 109, 84 Eng. Rep. 1103 (K.B. 1700?).

82. Id. at 110, 84 Eng. Rep. at 1104. 
1) If the gun were discharged at the King's officers and the shot killed Harding accidentally, it would have been murder by the entire gang, including Plummer, because it would then have been done pursuant to their common felonious design and common design to resist arrest; but the jury did not find that the gun was so discharged, and the judges must confine themselves to the facts as found..$^{83}$

2) If the gun were discharged deliberately at Harding, the shooter would obviously be guilty of murder; but the others would not. The murder was not done in prosecution of their unlawful purpose and the others did not know it was intended. "This notion that hath been received, that if divers persons be engaged in an unlawful act, and one of them kills another, it shall be murder in all the rest, is very true; but it must be admitted with several qualifications." 84 Holt then advanced four qualifications:

a) "the abettor must know of the malicious design of the party killing";

b) "the killing must be in pursuance of that unlawful act, and not collateral to it"; ${ }^{85}$

c) "the unlawful act ought to be deliberate"; 86

d) "as the unlawful act ought to be deliberate to make the killing murder, so it ought to be such an act as may tend to the hurt of another either, immediately, or by necessary consequence." 87

The two latter qualifications are of doubtful application and were not necessary to the decision in Plummer. The Chief Justice recognized this when he stated the ratio decidendi of the case:

"These things I thought fit to mention, though some of them are not such premisses from which the conclusion to this matter in question may be drawn, yet they all tend to illustrate the matter and reason that we rely upon, which is, that though the person that shot off the fuzee against the person slain did it maliciously, and so it would be murder in him, yet the others not knowing of his design against that person cannot be adjudged to be aiders and abettors of that murder." 88

83. Id. at 111, 84 Eng. Rep. at 1104.

84. Id. at 113, 84 Eng. Rep. at 1105.

85. Ibid.

86. Id. at 115, 84 Eng. Rep. at 1106.

87. Id. at 116, 84 Eng. Rep. at 1107.

88. Id. at 117-18, 84 Eng. Rep. at 1107. 
Plummer is sound by more modern analysis. The killing occurred only temporally "in the course of" the crime, it was not "in furtherance of" it, and "in the course of" requires some purposive relationship between the lethal act and the crime in so far as accomplices are to be held liable for the death; the shot was not fired pursuant to the common purpose to resist arrest-if it were found as a fact that it had been fired for this purpose and had chanced to kill Harding, then it would be murder in all, but it was not so found; the killing of Harding was not "within the risk" of the common criminal design-that Harding might be killed by a King's man or accidentally in the melée may well be foreseeable and within the risk, but not that he should be killed in this way. ${ }^{89}$

In his judgment Chief Justice Holt hinted at the true facts in Plummer, implying that when the gang realized that they had walked into a police trap one of their number assumed that it was Harding who had informed the police of their plans and shot Harding by way of revenge. ${ }^{80}$

Plummer has been stated at length because of the care given to its decision and because of its sharp conflict with a 1939 decision of a California appellate court, People v. Cabaltero. ${ }^{91}$ Cabaltero and six other laborers conspired to rob the farm of Nishida at the time he was paying the wages of his men. Cabaltero waited outside in an automobile to provide the means of escape; Ancheta, another conspirator, stood

89. FosTER, op. cit. supra note 46 , at $351-52$ offers a similar analysis, stressing that to render co-conspirators liable in this type of situation, the murder must be committed "in prosecution of some unlawful purpose, some common design, in which the combining parties were united, and for the effecting whereof they had assembled; for unless this shall appear, though the person giving the mortal blow may himself be guilty of murder . . yet the others who came together for a different purpose will not be involved in his guilt. ..." Foster then states Plummer and concludes: "I take it, that the point, on which the case turned, was this; it did not appear, from any of the facts found, that the gur was discharged in prosecution of the purpose for which the party was assembled. But had it been positively found, that it was discharged against the officer or his assistants, the court upon this finding might, without incroaching upon the province of the jury, have presumed, that it was discharged in prosecution of their original purpose. In cases so circumstanced, res ipsa loquitur."

90. In The King v. Hodgson, 1 Leach 6, 168 Eng. Rep. 105 (K.B. 1730), Plummer was discussed and its rationale applied. The prisoners had been hired to assist a decamping tenant to carry away his household furniture to prevent it being distrained for arrears of rent. The landlord had assembled a rival group. Both groups armed themselves with bludgeons and similar offensive weapons. A violent affray ensued. The constable unsuccessfully tried to disperse the mob. During the fight, one of the company, never identified, killed a boy standing at his father's door looking on but totally unconcerned in the affray. The question whether this was murder in all the company was reserved for the judges of the King's Bench and the circuit judges. They held, Holt, C.J. and Pollexfen, C.J. dissenting, that as the homicide "did not happen in prosecution of the illegal act ... the persons . . . could not be said to be aiding and abetting the death of one who was totally unconcerned in the design for which the parties had assembled." The court in Almeida uses the dissenting position of the two chief justices to buttress its position, and brushes aside without discussion the views of the majority in that case. $362 \mathrm{~Pa}$. at 618-19, $68 \mathrm{~A} .2 \mathrm{~d}$ at $606-07$.

91. 31 Cal. App. 2d 52, 87 P.2d 364 (1939). 
guard at the door. The others entered the building; all but one were armed. A car drove up, and Ancheta told the two occupants of the car to stay in it. They jumped out and ran away. Ancheta fired two shots at them. Immediately one of the conspirators, Dasalla, emerged from the building, exclaimed to Ancheta, "Damn you, what did you shoot for," and fired a shot at Ancheta, wounding him. All the conspirators, having obtained the money they sought, then got into the car driven by Cabaltero. Dasalla and two others picked Ancheta up and assisted him into the car. Ancheta died two weeks later from the effects of the wound.

The charge against all six was based on section 189 of the California Penal Code: "All murder which is . . . committed in the perpetration or attempt to perpetrate arson, rape, robbery, burglary, or mayhem, is murder in the first degree . . . ."

All the conspirators, except the one who was unarmed, were convicted under this section of first degree murder. Their appeals were dismissed. The appellate court held that if the killing occurs in the perpetration of the robbery, the killer is liable whether his act was "willful, deliberate and premeditated" or whether it was "absolutely accidental," and further that:

"[I]f a homicide is committed by one of several confederates while engaged in perpetrating the crime of robbery in furtherance of a common purpose, the person or persons engaged with him in the perpetration of the robbery but who did not actually do the killing, are as accountable to the law as though their own hands had intentionally fired the fatal shot . . . and such killing is murder of the first degree. The jury has no option but to return a verdict of murder of the first degree whether the killing was intentionally or accidentally done, and it is proper so to instruct the jury." 92

The argument that the killing was not done "in the perpetration" of the robbery was disposed of on simple temporal grounds: "here the killing was done while the conspirators were attempting to flee from the scene of the robbery with the fruits thereof in their possession. Therefore the homicide was committed in the perpetration of the robbery." ${ }^{93}$

Given this interpretation of the section, the rest follows. The killing will be murder by all the accomplices to the felony "irrespective of the status of the person killed and regardless of whether the killing is accidental or intentional." 94 The court expressly denied to the conspirators "the benefit of the doctrine that if one member of a

92. Id. at $57,87 \mathrm{P} .2 \mathrm{~d}$ at 366 .

93. Id. at $61-62,87$ P.2d at 369 .

94. Id. at $58,87 \mathrm{P} .2 \mathrm{~d}$ at 367 . 
conspiracy departs from the original design as agreed upon by all members, and does an act which was not only not contemplated by those who entered into the common purpose but was not in furtherance thereof, and not the natural and probable consequence of anything connected therewith, the person guilty of such act . . . is alone responsible therefor." It denied them this "benefit" again on purely temporal grounds: "Such doctrine is not available, however, to coconspirators in cases such as this, where the killing is done during the perpetration of a robbery in which they were participating." 95

There is little to be said in favor of this decision. Applying the expressed ratio of Cabaltero, if one of two burglars ransacking a home glances out of a window, sees his enemy for whom he has long been searching and shoots him, the unarmed accomplice, party only to the burglary, will be guilty of murder in the first degree.

Historically, a close causal relationship between the crime and the killing has always been required. ${ }^{96}$ Of course, the fact that the killing was accidental does not prevent this causal relationship from existing, for it does not put the death outside the risk of the crime, and there may well be liability on all accomplices for an accidentally lethal act during the course of the commission of the felony. Several times the Cabaltero court supported its view of the appropriateness of a conviction in that case by reference to such accidentally lethal acts; but these stand on a quite different footing to the lethal acts in Plummer and Cabaltero which were not accidental but which were, on the evidence, the deliberate acts of one accomplice, outside the conspiracy, "outside the risk" of the conspiracy, and serving only his personal animus.

The California Penal Code, ${ }^{97}$ like the Pennsylvania statute, merely categorizes certain "murders" as murders in the first degree. Given a "murder," temporal congruence between it and a felony of arson, rape, robbery, burglary or mayhem by the murderer makes his offense that of murder in the first degree. But the first step, the definition of the crime as "murder" under the common law, has always been held to require some causal and not merely temporal connection between the killing and the felony. The court in Cabaltero apparently ignores this necessity for a consideration of the common-law felony-murder rule as a preliminary step in the application of the statutory felonymurder rule.

Finally, it is submitted that there is no social utility in the Cabaltero decision. The lethal act is unexpected and undesired. The

95. Id. at 61,87 P.2d at 368 .

96. Perkins, The Law of Homicide, 36 J. Crim. L., C. \& P.S. 391,404 (1946).

97. Cal. Prin. Code ANn. $\S 189$ (West 1955). 
accomplices, other than the killer, should not be held to anticipate this type of internecine strife. This widening of the definition of murder can have no deterrent effect; nor does it conform with the layman's instinctive primordial definition of murder. The Plummer rule is greatly to be preferred and the statement by Stephen ${ }^{88}$ that "if any of the offenders commits a crime foreign to the common criminal purpose, the others are neither principals in the second degree nor accessories unless they actually instigate or assist in its commission" states both the common law and sound policy. ${ }^{99}$

\section{Does Arrest Terminate a Felon's Criminal Responsibility for Subsequent Lethal Acts by His Co-Felon?}

Authority is not required for the proposition that a conspirator in a felony may withdraw from the conspiracy provided he does so by effective and timely means. He will remain liable for the conspiracy itself but not for a crime subsequently committed or for any of its unintended and possibly lethal consequences. The means of his withdrawal will generally be effective if brought to the attention of the other parties before the commission of the crime in time for them to desist from it. ${ }^{100}$

Will a "withdrawal" as a result of arrest have the effect of insulating the arrested felon from liability for any unintended lethal consequences of the felony on which he and his co-felons had originally embarked? The question is an important and difficult one on which there is scant authority.

The early English case of Jackson, reported by Hale, ${ }^{101}$ offers one answer to this question. Jackson and four others committed a robbery. They were pursued by "the country, upon hue and cry

98. Stephen, A Digest of the, CRiminal LAw 17 (9th ed. 1950).

99. The views here advanced concerning collateral force conform with the recommendations in the Model PeNAL Code $\$ 2.04(4)$, at 34 (Tent. Draft No. 1, 1953). "If the homicidal act was not a means to the commission of the robbery-as if one party shoots an enemy in satisfaction of a merely private grudge-complicity in the robbery would not imply complicity in murder, because it did not comprehend the causitive behavior." The inclusion in a footnote of the tentative draft, $i d$. at 25 , of the case of Cabaltero with that of People v. Michalow, 229 N.Y. 325, 128 N.E. 228 (1920) is, it is submitted, incorrect. Michalow supports the view of an accomplice's liability for which the draft contends; Cabaltero goes well beyond it.

100. -Karnes v. State, 159 Ark. 240, 252 S.W. 1 (1923); People v. King, 30 Cal. App. 2d 185, 85 P.2d 928 (1938) ; People v. Ortiz, 63 Cal. App. 662, 219 Pac. 1024 (1923); Pinkard v. State, 30 Ga. 757 (1860); People v. Marx, 291 I11. 40, 125 N.E. 719 (1919) ; Pollack v. State, 215 Wis. 200, 253 N.W. 560 (1934). But such notice to the other conspirators is not essential. Notice to police authorities in time to help prevent the felony may suffice. See State v. Bigley, 53 Idaho 636, 26 P.2d 375 (1933), in which the accused repented of his collaboration in a plan to rob a bank, notified the bank authorities of the plan, was persuaded by them to continue to pretend to be involved in the plan and thus assist in the capture of the felons. This he did. He was held to have effectively withdrawn from the felony.

101. 2 Hale, Pleis of the Crown 464 (1st Am. ed. 1847). 
levied." In a field they turned and fought back; Jackson killed one of the pursuers. It was held that Jackson and three of his confederates were guilty of murder "in as much as . . . [they] were of a company, and made a common resistance, and so one animated the other . . .," but that ". . . when one of the malefactors was apprehended a little before the party was hurt, that person being in custody when the stroke was given was not guilty, unless it could be proved, that after he was apprehended he had animated Jackson to kill the party." 102 This conclusion, stated in this form, is too generous to the accused. Should not the essential issue be whether the aiding and abetting, the counselling or instigating-the "animating" in Hale's terms-is operative at the time of the lethal act? Arrest may mark the point of cessation of this actively, but there is no reason why it should do so in all cases.

The Pennsylvania case of Commonrealth $v$. Doris ${ }^{103}$ is an example of liability for a lethal act by a co-felon committed subsequently to arrest. Doris and three others ${ }^{104}$ robbed a truck transporting money between two branches of a bank. Masked, heavily armed and shooting continuously, they held up the van and seized bags of currency. A policeman stationed nearby disabled the criminals' car by firing into its motor. In the melée Doris was captured. The other three took forcible possession of a horse-drawn milk wagon and endeavored to escape therein. A policeman gave chase in a passing truck. Within a few moments he was killed by a bullet fired by one of the felons. ${ }^{105}$

There was no doubt of Doris' participation in the common felonious purpose up to the point of his arrest and, had he not been arrested, of his responsibility for the death of the police officer by virtue of the felony-murder rule and the co-felon rule. The court concluded that the fact of arrest prior to the killing made no difference to his liability for the murder, holding that, to avoid this type of responsibility for the common felonious design upon which he had embarked, "there must be an actual and effective voluntary withdrawal before the act in question has become so imminent that its avoidance is practically out of the question." 106

102. Ibid. The social significance of this result is lessened by the conclusion of Hale's report of the case: "They had all judgment of death for the robbery, and four of them for the murder." Id. at 465. Nevertheless the fifth man's offense may have, for him, been clergyable and the verdict may have in fact spared his life.

103. $287 \mathrm{~Pa} .547,135$ Atl. 313 (1926).

104. There was possibly a fifth conspirator who was not apprehended.

105. The facts of this crime are stated in Commonwealth v. Bentley, $287 \mathrm{~Pa} .539$, 542, 135 Atl. 310, 311. Bentley was one of Doris' confederates.

106. $287 \mathrm{~Pa}$. at 552, $135 \mathrm{Atl}$. at 315. See also, supporting this conclusion, State v. Klein, 97 Conn. 321, 116 Atl. 596 (1922) ; People v. Nichols, 230 N.Y. 221, 129 N.E. 883 (1921) ; People v. Chapman, 224 N.Y. 463, 121 N.E. 381 (1918). 
The problem is raised in a more difficult form in the English case of Craig and Bentley, ${ }^{107}$ where the eighteen-year-old Bentley was convicted and hanged for the murder of a policeman, the lethal shot having been fired by his sixteen-year-old co-felon, Craig, some twenty minutes after Bentley had submitted to the police. However, the particular question of the effect of arrest was not decided, first, because of the prosecution's reliance on Bentley's alleged shouted advice to Craig, "Let 'em have it, Chris," after Bentley was in police custody; and second, with less reason, because of the Court of Criminal Appeal's view that Bentley's ridiculous statement at trial that he was not under arrest at the time of the killing-which he manifestly was-had the effect of denying to him an exculpatory argument based on that fact. ${ }^{108}$

What then are-or, in the present lack of authority, should bethe rules on this matter?

Commonwealth v. Doris and People v. Nichols ${ }^{109}$ are persuasive authority for the proposition that:

"Whatever may be the other requirements of an effective abandonment of a criminal enterprise, it is certain both as a matter of law and of common sense that there must be some appreciable interval between the alleged abandonment and the act from responsibility for which escape is sought. It must be possible for the jury to say that the accused had wholly and effectively detached himself from the criminal enterprise before the act with which he is charged is in the process of consummation or has become so inevitable that it cannot reasonably be stayed." 110

Given then that the arrest is not closely related in time to the lethal act, may it constitute an effective withdrawal? Foster makes this type of liability depend on the co-felons' "reasonable expectation of mutual defence and support," 111 and there is much to be said for this

107. Hyde, Trial of Christopher Cratg and Derek Willtam Bentieiy (Notable British Trial Series 1954).

108. It is not the formal proceedings of "arrest," pursued by the police officer, which is significant to this question; it is the submission (or subjection) to police control. Bentley's views as to this are surely irrelevant unless it be argued that because he denied "arrest" he must therefore be assumed to deny the fact that he was under police control for some twenty minutes before Craig's fatal shooting of the police officer, which is absurd.

109. 230 N.Y. 221,129 N.E. 883 (1921).

110. Id. at 229,129 N.E. at 885 . Nichols had waited until his co-felon and the person they were robbing were grappling with each other, and his co-felon had his gun over their victim's heart, before he shouted his intention to abandon the enterprise and fled the scene.

111. " $A, B$ and $C$ ride out together with intention to rob on the highway. $C$ taketh an opportunity to quit the company, turneth into another road, and never joineth $A$ and $\mathrm{B}$ afterwards. They upon the same day commit a robbery. $\mathrm{C}$ will not be considered an accomplice in this fact. . . Nor was there at the time the fact was committed any engagement or reasonable expectation of mutual defence and support so far as to affect him." Foster, Crown CASES ANd CROWN LAw 354 (1st ed. 1767). See also 1 HALE, op. cit. supra note 101, at 537. 
view. If this be controlling, then if the killer knows of his accomplice's submission to arrest this should render the person so submitting no longer responsible for the future acts of his recent accomplice. ${ }^{112}$ One compelling policy argument for this line of reasoning is the wisdom of making it safe to submit to arrest; if, resisting or not, a criminal is liable to be convicted of murder because of his confederate's acts, he will be ill-advised to submit.

If the killer does not know of his accomplice's submission to arrest, different considerations arise. The killer may well be supported and confirmed in his criminal acts by his mistaken belief in his accomplice's continued participation in the crime. It may therefore be necessary to draw a distinction between cases where the accomplice knows and does not know of his confederate's submission to arrest; but the universal value of such a distinction is to be doubted. Surely, the fact that the felon persisting in the crime or resistance to arrest does not know of his co-felon's submission, should not fix on the latter liability for lethal acts of the former committed appreciably later. How long should the risk of such liability remain? Only an argument of convenience, of general causal responsibility, of some recent reliance by the killer on his co-felon's participation in the crime may aid us in drawing this line at some point of time and at some point of proximity to the lethal harm. On these imprecise grounds it is tentatively submitted that the arrested accomplice should be liable only for such consequences as flow from the encounter at which he submitted to arrest, and that if his accomplice eludes the police and, ignorant of his submission, is later engaged by them, the arrested felon should not be liable for his accomplice's subsequent lethal act.

The matter has been discussed so far on the basis of a submission to arrest. Is the result to be different if the arrest is forcefully effected against the felon's will? ${ }^{113}$ In Doris, Justice Sadler stated that Doris' abandonment of the criminal enterprise, prior to the killing, to be effective to exculpate him from responsibility "must have been his voluntary act." 114 It is true that the policy reasons in the case of forceful arrest are very much less compelling than when there has been

112. This is subject, of course, to the principle enunciated in Doris and Nichols that the submission is not at a time when the lethal act is imminent. Chief Justice Hiscock in Nichols gave good reason for this qualification: "The process of detachment must be such as to ... give his co-conspirators a reasonable opportunity, if they desire, to follow his example and refrain from further action before the act in question is committed." 230 N.Y. at 229,129 N.E. at 885 .

113. It is, of course, often extremely difficult to distinguish a voluntary submission to police control from one effected by superior police force-the criminal's recognition of the futility of resistance to such overwhelming force may well lead him to a "voluntary" submission.

114. $287 \mathrm{~Pa}$. at 552, 135 Atl. at 315. 
voluntary submission to arrest; but nevertheless it is submitted that forceful arrest just as voluntary submission should render the arrested accomplice immune from liability for the murder subsequently committed by his accomplice, if the fact of his arrest is known to that accomplice or there is a substantial lapse of time between the arrest and the killing. It is the "animating" at the time of the lethal act which is significant, not the manner of withdrawal from the enterprise. ${ }^{115}$

\section{Liability of a Felon When His Co-Felon Accidentally Kills Himself}

Should co-felons be liable under the felony-murder rule if one of their number accidentally kills himself while committing the felony? The only two cases which have been found in which this question had to be determined under the common-law rules ${ }^{116}$ are in conflict-the California case of People v. Ferlin ${ }^{117}$ and the Pennsylvania decision in Commonwealth v. Bolish. ${ }^{118}$ The view of the facts accepted by both courts as a basis for their discussion are so similar as to be capable of a single statement: in each the accused hired a youth to burn down some property; the youth burnt himself badly in the process and died. In Ferlin the court held that on these facts the accused must be acquitted of murder, because "it cannot be said . . . that defendant and deceased had a common design that deceased should

115. The American Law Institute's Model Penal Code offers the following general provision on the question of an accomplice's ability to withdraw from complicity in a crime so as to avoid accessorial responsibility for it:

"(5) Unless otherwise provided by the definition of the crime, a person is not an accomplice in a crime committed by another if :

$\cdots$...

(c) he terminated his complicity prior to the commission of the crime and

(1) wholly deprived it of effectiveness in the commission of the crime; or

(2) gave timely warning to the law enforcement authorities or otherwise made proper effort to prevent the commission of the crime."

Model Penal. Code $\$ 2.04(5)$ (Tent. Draft No. 1, 1953). In the commentary, id. at 37, it is explained that, "The general principle advanced is that the accomplice must deprive his complicity of its effectiveness. The action needed for that purpose will, of course, vary with the accessorial behaviour." The Code does not deal with the particular problem discussed in the text, but it is submitted that the views here advanced are in accord with the general approach of the code.

116. The New York Supreme Court's decision in People v. La Barbera, 159 Misc. 177, 287 N.Y. Supp. 257 (Sup. Ct. 1936) was based on facts similar to those in Ferlin and Bolish, but is distinguishable from the problem in the text in that it was decided upon the New York statute which repeals the common-law rules of felonymurder and provides expressly that homicide is "the killing of one human being by act, procurement, or omission of another." N.Y. PEN. LAW \$1044. On the view of the facts that Gagliano, the deceased, was the accomplice in arson of the accused, $\mathrm{La}$ Barbera, and that in the prosecution of that felony Gagliano burned himself to death, the accused was held under the statute not to be guilty of murder. It was not the killing of one by another.

117. 203 Cal. 587, 265 Pac. 230 (1928).

118. $381 \mathrm{~Pa} .500,113$ A.2d 464 (1955). 
accidentally kill himself. Such an event was not in furtherance of the conspiracy, but entirely opposed to it." 119 In Bolish by a majority (six to one) it was held that a conviction for murder in the first degree would be open to the jury in these circumstances, the reasoning being essentially the same as that advanced in Almeida. ${ }^{120}$

In that it has been argued that Almeida was an unwise decision, not justified by the authorities on which the court sought to rely, the decision in Bolish would require no further discussion were it not for a significant difference between it and Almeida. The three types of cases which the majority in Almeida used and grouped together to lend the force of authority to their decision were cases where the felon's act or that of his co-felon was a directly lethal act, the "shield" cases and the "out of the frying pan" cases. Though the first group do not, it has been submitted, justify imposing liability under the felonymurder rule for retaliatory force, they do appear to justify the imposition of such liability in the Ferlin and Bolish situation. They cover crimes where the felon or his co-felon deliberately sets fire to a building for purposes of collecting the insurance money and a fireman is killed in endeavoring to put out the fire; otherwise the three-fold categorization of the authorities is inadequate. ${ }^{121}$ It is generally accepted and there is supporting authority ${ }^{122}$ that there can be a conviction of murder in the first degree in the arson-death-of-a-fireman type of case. In Ferlin and Bolish, the direct lethal act was clearly that of the co-felon; the analysis used to reject Almeida and Thomas is not therefore sufficient to support Ferlin and to reject Bolish.

Will the Ferlin ratio suffice-that is, is it sufficient to deny liability for murder in these cases by stating, what is manifestly true, that the killing was not the common design of the co-felons and was not in furtherance of the felony? ${ }^{123}$ The difficulty is that in the fireman type of case both these propositions hold true, as indeed they do in respect of the arson of any premises in which it is believed people are or may be present; though no intent to kill exists. ${ }^{124}$

119. 203 Cal. at 597, 265 Pac. at 235.

120. See pp. 51-53 supra.

121. Surprisingly enough, in neither Almeida, Bolish nor Thomas did the Pennsylvania Supreme Court deal directly with this type of case which would, at first sight, seem to support their decisions in these cases better than many of the authorities they relied upon.

122. State v. Glover, 330 Mo. 709, 50 S.W.2d 1049 (1932).

123. Musmanno, J. based his dissent in Bolish on this argument. Jones, J., who dissented in Almeida and Thomas, concurred in the intervening case of Bolish in a brief opinion in which he regarded himself as coerced by the decision in Almeida.

124. In many applications of the felony-murder rule to co-felons, the killing, as distinct from the felony, is neither within the felons' common design nor in furtherance of it. In Ferlin and Bolish the felony of arson which was the directly lethal act was within the common design and in furtherance of it. 
Further, it has been submitted that a distinction between Almeida and Thomas need not be drawn along the suggestion that the felon who was killed in the latter case, as distinguished from the policeman in the former, was volens to this type of risk and, because he was a felon, put himself outside the protection of the law of murder. It was possible to reject both decisions on other grounds.

As revealed in Regina $v$. Serné, ${ }^{125}$ the crime of arson has proved difficult to blend into the felony-murder rule with even a show of justice. But if it be accepted that the felony-murder rule fixes the arsonist with liability for the death of a fireman or of a policeman or of a neighbor endeavoring to save the building or its contents, the only ground of distinction between those cases and the Ferlin-Bolish type of case is to be found along some application of the volenti principle. Whether such a distinction is to be drawn or not is a matter of policy. Despite the novelty of the idea, it is easier to reconcile with established doctrine liability in the Ferlin and Bolish type of case, ${ }^{126}$ where the lethal act is that of the felon or co-felon, than it is in the situations where death is a result of retaliatory lethal force precipitated by the felony. ${ }^{127}$ Authority apart, however, there is little purpose to be served by a verdict of murder in the first degree. As was suggested concerning liability for retaliatory force, the deterrent effect of such a result is very doubtful; the increased punishment strikes at the wrong thingnot at the harm intended, but at the slight chance of an unintended greater harm; and emotions of vengeance are an insufficient justification for the fictional attribution of the mens rea of murder to one whose desire was quite certainly not a desire to kill.

In Ferlin the court suggested that, ". . . if the defendant here is guilty of murder because of the accidental killing of his co-conspirator then it must follow that Skala [the youth who set the fire and killed himself] was also guilty of murder, and if he had recovered from his burns that he would have been guilty of an attempt to commit murder." ${ }^{128}$ This reveals a massive confusion. There is no offense of suicide in California, but even if there were Skala could not be guilty of suicide (regardless of whether Ferlin had been convicted of

125. 16 Cox C.C. 311 (Cent. Crim. Ct. 1887).

126. Moesel, A Survey of Felony Murder, 28 TEMp. L.Q. 453, 462 (1955) perstrasively supports the decision in Bolish and criticizes the decision in Ferlin as a misapplication of the civil law "agency theory" to the liability of co-felons under the felony-murder rule.

127. The applicability of the felony-murder rule to the situation where one felon kills himself by an act in furtherance of the felony illustrates "the tendency of a principle to expand itself to the limit of its logic." Cardozo, THE NATURE OF THE JUDICIAL PROCESS 51 (1921). The retaliatory force cases illustrate the tendency of a principle, where high feelings are involved, to burst the bonds of logic.

128. $203 \mathrm{Cal}$. at 596, $265 \mathrm{Pac}$. at 234. 
murder) because there is no doctrine of constructive suicide, while the felony-murder rule is a doctrine of constructive murder, of imputing a certain mental intent whether or not it in fact exists. Suicide clearly requires an intent to kill. Likewise, though there is a doctrine of constructive murder, there is no doctrine of constructive attempted murder. The attempt requires a full intent to kill, whereas the completed crime does not.

However much one may feel that the law poorly fulfills its functions by declaring accused persons in the Ferlin-Bolish situations to be murderers, this result can be avoided without violence to logic only if the felony-murder rule itself be modified-which might well be desirable - or if it be accepted that the deceased felon so deliberately risked his life when he entered upon the felony that this confederate should not be held criminally responsible for his death. ${ }^{229}$

129. One arranging for a co-felon to splash petrol or kerosene about in a house and then to ignite it recklessly risks killing that co-felon. Here, as for deaths from force retaliatory to a felony, the theory of involuntary manslaughter more accords with the spirit of the criminal law than does murder. 